\title{
A NOTE ON THE BLOOD GROUPS OF COMMONWEALTH IMMIGRANTS TO ENGLAND*
}

\author{
BY \\ IAN LECK, M.B., Ph.D. \\ Medical Unit, University College Hospital Medical School, London, and Department of Social Medicine, \\ University of Birmingham
}

The occurrence in recent years of widespread immigration to England from other Commonwealth countries, and the subsequent miscegenation, have provided new opportunities for clarifying the aetiology of various malformations, tumours, and other conditions of uncertain cause which differ in incidence according to ethnic group. As well as being of general anthropological interest, information about the blood groups of these immigrants is particularly needed to indicate how much the genetic origins of the West Indians among them differ from those of negroids in the United States of America-a question of some importance now that the previous, mainly American, studies of the differences in disease incidence between caucasoids and negroids living in the same localities can be compared with English data.

\section{MATERIAL}

Demographic and medical data relating to all births to Birmingham residents have been recorded on punch cards in the municipal health department since 1949 (Charles, 1951). This note deals with the records of births in 1959. Ninety-eight per cent. of these records include the ethnic origins of both parents, reported by the city's health visitors for infants seen by them, and by midwives and other maternity hospital staff for stillborn children and those who died without a health visitor seeing them. ABO blood group was recorded for $88 \%$ and $\mathrm{Rh}(\mathrm{D})$ group for $92 \%$ of the mothers of children of known ethnic group; this information was derived from the clinical notes of their pregnancies, encoded after being abstracted by midwives, other maternity hospital staff, and technicians from the University Department of Social Medicine.

\section{RESUlts}

Apart from children of half-European parentage

-This work was assisted by a grant from the Association for the Aid of Crippled Children, New York. (for whom it was not stated which parent was European), the only ethnic groups of more than 100 births which could be distinguished were those with European, West Indian, and Indian or Pakistani parents. The blood groups of the mothers of these children are shown in Table I, together with their estimated gene frequencies (calculated by the methods used by Mourant (1954)).

\section{Discussion}

\section{ReLiability of Findings}

The blood group gene frequencies estimated for those of European descent in the present series (Table I) are well within the ranges observed in previous English studies (assembled by Mourant (1954) and Mourant, Kopeć, and DomaniewskaSobczak (1958)). Gene A seemed to be present in about $1 \%$ fewer cases than in previous series from the English West Midlands, and gene $O$ in correspondingly more, perhaps because the proportion of pregnant women in Birmingham who are of Irish origin is relatively high (Leck, 1969); but there is nothing in the European figures to suggest any more severe bias in the data. The estimates for women from India and Pakistan-showing a 7\% deficiency of gene $\mathrm{A}$ and excess of gene $\mathrm{O}$ relative to the average for these countries, and figures for genes $\mathrm{B}, \mathrm{D}$, and $\mathrm{d}$ within normal limits-are based on too few cases to justify attaching much importance to them.

Among the countries of origin of the West Indian immigrants, Jamaica and Trinidad seem to be the only two from which blood group distributions have been reported, and the data from Trinidad are affected by the substantial Asiatic Indian community there, which contributed little if at all to the present series. The Jamaican findings and those for West Indians in Birmingham are compared in Table II, together with figures for West African and British populations (representing the main ethnic origins of the West Indians).

The differences between the Jamaican findings and the present series were negligible in respect of 
TABLE I

BLOOD GROUPS OF BIRMINGHAM WOMEN WHO GAVE BIRTH TO CHILDREN IN 1959

\begin{tabular}{|c|c|c|c|c|c|c|c|}
\hline \multirow{2}{*}{\multicolumn{2}{|c|}{ Ethnic Group }} & \multicolumn{2}{|c|}{ European } & \multicolumn{2}{|c|}{ West Indian } & \multicolumn{2}{|c|}{ Indian or Pakistani } \\
\hline & & No. & $\%$ & No. & $\%$ & No. & $\%$ \\
\hline \multirow[t]{2}{*}{$\begin{array}{c}\text { ABO } \\
\text { phenotypes }\end{array}$} & $\begin{array}{l}\mathbf{O} \\
\mathbf{A} \\
\mathbf{B} \\
\mathbf{A B}\end{array}$ & $\begin{array}{r}7,447 \\
6,383 \\
1,288 \\
407\end{array}$ & $\begin{array}{r}47 \cdot 97 \\
41 \cdot 11 \\
8 \cdot 30 \\
2 \cdot 62\end{array}$ & $\begin{array}{r}454 \\
204 \\
159 \\
40\end{array}$ & $\begin{array}{r}52 \cdot 98 \\
23 \cdot 80 \\
18 \cdot 55 \\
4 \cdot 67\end{array}$ & $\begin{array}{r}45 \\
13 \\
36 \\
9\end{array}$ & $\begin{array}{r}43 \cdot 69 \\
12 \cdot 62 \\
34.95 \\
8 \cdot 74\end{array}$ \\
\hline & Total known & 15,525 & $100 \cdot 00$ & 857 & $100 \cdot 00$ & 103 & $100 \cdot 00$ \\
\hline $\begin{array}{l}\text { ABO } \\
\text { genes }\end{array}$ & $\begin{array}{l}\mathbf{O} \\
\mathbf{A} \\
\mathbf{B}\end{array}$ & & $\begin{array}{r}69 \cdot 37 \\
25 \cdot 00 \\
5 \cdot 62\end{array}$ & & $\begin{array}{l}72 \cdot 28 \\
15 \cdot 38 \\
12 \cdot 34\end{array}$ & & $\begin{array}{l}64 \cdot 14 \\
11 \cdot 19 \\
24 \cdot 66\end{array}$ \\
\hline \multirow{2}{*}{$\begin{array}{c}\mathbf{R h} \\
\text { phenotypes }\end{array}$} & $\begin{array}{l}\mathbf{R} \mathbf{h}+ \\
\mathbf{R} \mathbf{h}-\end{array}$ & $\begin{array}{r}13,675 \\
2,676\end{array}$ & $\begin{array}{l}83 \cdot 63 \\
16 \cdot 37\end{array}$ & $\begin{array}{r}826 \\
62\end{array}$ & $\begin{array}{r}93 \cdot 02 \\
6 \cdot 98\end{array}$ & $\begin{array}{r}100 \\
10\end{array}$ & $\begin{array}{r}90.91 \\
9.09\end{array}$ \\
\hline & Total known & 16,351 & $100 \cdot 00$ & 888 & $100 \cdot 00$ & 110 & $100 \cdot 00$ \\
\hline$\underset{\text { genes }}{\mathbf{R h}}$ & $\stackrel{D}{d^{\text {or }} \mathrm{D}^{u}}$ & & $\begin{array}{l}59 \cdot 55 \\
40 \cdot 45\end{array}$ & & $\begin{array}{l}73 \cdot 58 \\
26 \cdot 42\end{array}$ & & $\begin{array}{l}69 \cdot 85 \\
30 \cdot 15\end{array}$ \\
\hline
\end{tabular}

TABLE II

BLOOD GROUP GENE FREQUENCIES IN CAUCASOID, NEGROID, AND MIXED POPULATIONS

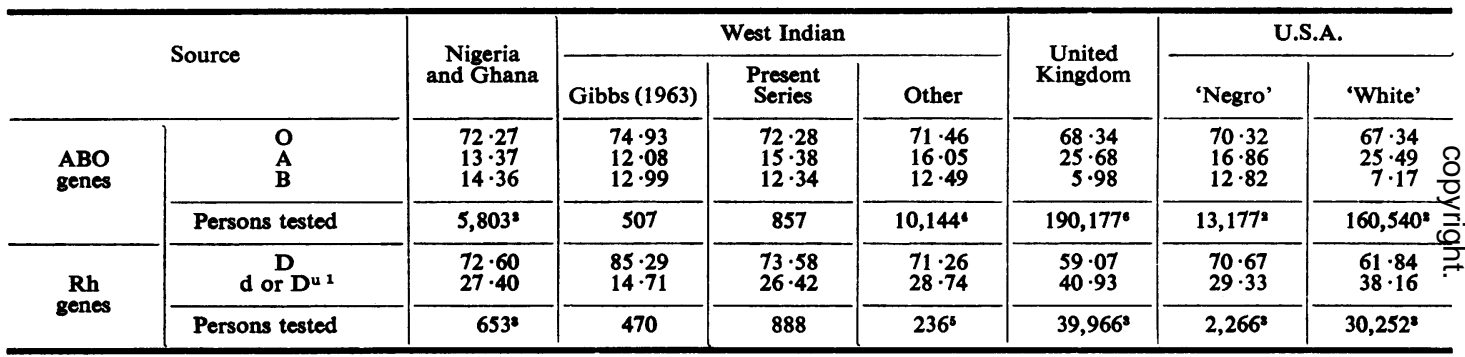

1 Data on Du gene frequencies were not available for most series.

All the series assembled by Mourant, Koped, and Domaniewska-Sobczak (1958).

- All the series assembled by Mourant (1954), with the exception of one Ghanaian and one American negro series which differed from the remainder and would have affected the pooled figures so markedly that it seemed better to omit them: these two series included $14 \%$ and $15 \%$ respectively of D-negative individuals, in contrast to figures within the range 6-9\% for the five other West African series given, and 6-11\% for the other nine from the U.S.A.

- Snyder (1929) and Milner (1965).

Stafford, Hill, and Arneaud (1955).

- Dobson and Ikin (1946).

gene B; the other gene frequencies for the immigrants were intermediate between the figures given by Gibbs (1963) on the one hand and those of Snyder (1929), Milner (1965), and Stafford, Hill and Arneaud (1955) on the other. This finding is in favour of the present series being representative, since the Jamaican samples were probably taken from opposite extremes of the population. The figures given by Gibbs (which, except for the B gene, differed even more than the West African figures from those found in British people) were observed in a relatively remote community where there is likely to have been much more genetic drift and less miscegenation than in the island generally. The data of Stafford et al. and Milner, on the other hand, came from University Hospital, near Kingston-an area where the caucasoid element in the ancestry of the inhabitants, and especially of the more privileged, seems to be greater than elsewhere; Snyder's data also were apparently collected in the course of a study of a relatively privileged group in which the proportion of individuals showing signs of part-caucasoid ancestry was exceptionally high.

\section{ETHNIC ORIGINS OF WeSt INDIANS AND U.S.A. NeGROES}

A comparison of the above findings with data from the United States of America (also included in Table II) suggests that the West Indian immigrants are more negroid and less caucasoid in ancestry than the North American negroes. Although the frequency of gene B in the two groups is similar, the American negroes are closer than the West Indians to the British and 'white' American populations in respect of all the other genes. Further evidence that the North American negroes are of more mixed descent than the West Indians is provided by figures 
TABLE III

ESTIMATED PERCENTAGE CONTRIBUTIONS OF CAUCASOIDS TO THE ANCESTRY OF WEST INDIAN AND U.S.A. NEGROES

\begin{tabular}{|c|c|c|c|}
\hline Population & West Indians & U.S.A. 'Negrc & s in Table II) \\
\hline $\begin{array}{l}\text { Source (in Table II) of gene frequencies postulated for caucasoid } \\
\text { ancestors }\end{array}$ & United Kingdom & United Kingdom & U.S.A. 'White' \\
\hline $\begin{array}{l}\text { Estimated contribution of caucasoid ancestors } \\
\text { Based on ABO data } \\
\text { Based on Dd data }\end{array}$ & $\begin{array}{c}18 \cdot 9 \\
-\end{array}$ & $\begin{array}{l}24 \cdot 8 \\
14 \cdot 3\end{array}$ & $\begin{array}{l}26 \cdot 7 \\
17 \cdot 9\end{array}$ \\
\hline
\end{tabular}

The estimates based on ABO and Dd data were computed by the methods of Stevens (1952) and Bernstein (1931) respectively, on the assumption that there were two parent populations, with gene frequencies identical to those given in Table II for Nigeria and Ghana on the one hand, and for either the United Kingdom or the U.S.A. 'white' population on the other.

for the cDe genotype, which is carried by more than half the Rhesus chromosomes of most African negro groups, and distinguishes them more sharply from populations elsewhere than does any other blood group of the Rhesus and ABO systems. The percentages of chromosomes estimated to be of this type were $52.2 \%$ and $45.5 \%$ in the Jamaican populations of Gibbs and Stafford et al. respectively, and $43.3 \%$ in the North American negro series assembled by Mourant.

Estimates in absolute terms of the amounts of mixing in the ancestry of the West Indian and North American negroes, based on ABO data for both groups and Dd data for the North Americans, are given in Table III. No estimate for the West Indians could be derived from their Dd gene frequencies since these were even further than the West African figures from those for caucasoids (Table II); it must therefore be concluded that the African ancestors of the West Indians, and presumably of the American negroes also, had a lower $d$ gene frequency than the African figure in Table II, which is based on relatively small numbers. The ABO data are more extensive and a much more reliable guide to the extent of mixing. They suggest a caucasoid element of $19 \%$ in the West Indians and $25-27 \%$ in the North American negroes. The true proportion for North American negroes may be higher, since negroes with marked caucasoid traits are thought to have been excluded from some American series for the sake of greater homogeneity.

\section{Summary}

Local authority records of all children born to Birmingham residents in 1959 were analysed according to ethnic origin and maternal $A B O$ and $R h(D)$ blood groups. From a study of the blood group frequencies observed in more than 800 immigrants from the West Indies in this population, and from data published previously, it is concluded that the caucasoid element in the ancestry of these West Indians is smaller than in the case of the negroes of North America, and probably does not exceed $20 \%$.
I am very much indebted to Dr. E. L. M. Millar (Medical Officer of Health, Birmingham) and his staff, and to Mrs. Eileen Armstrong, Miss Ida Giles, Mrs. Betty Mann, and the staff of local maternity units, for collecting and making available the Birmingham data and for help in its analysis; to Dr. A. E. Mourant, Dr. P. H. N. Wood, and Mrs. K. Domaniewska-Sobczak for drawing my attention to some of the material quoted from other sources; and to the Wates Foundation for financial support.

\section{REFERENCES}

Bernstein, F. (1931). Die geographische Verteilung der Blutgruppen und ihre anthropologische Bedeutung. Pp. 227-243. Comitato Italiano per lo Studio dei Problemi della Populazione. Instituto Poligraphico dello Stato, Rome.

Charles, E. (1951). Statistical utilization of maternity and child welfare records. Brit. J. soc. Med., $\mathbf{5}, 41$.

Dobson, A. M., and IkIN, E. W. (1946). The ABO blood groups in the United Kingdom; frequencies based on a very large sample. J. Path. Bact., 58, 221.

GIBBS, W. N. (1963). ABO and Rh blood group distribution in a rural Jamaican community. $W$. Indian med. J., 12, 103.

LECK, I. (1969). Ethnic differences in the incidence of malformations following migration. Brit. J. prev. Soc. Med., 23, 166.

Milner, P. (1965). Cited by Gore, D. (1965). Vagectomy with drainage procedure for duodenal ulceration. $W$. Indian med. J., 14, 247.

MoURANT, A. E. (1954). The Distribution of the Human Blood Groups. Blackwell, Oxford.

- Kopeć, A. C., and Domaniewska-SobczaK, K. (1958). The $A B O$ Blood Groups. (Royal Anthropological Institute Occasional Publication No. 13). Blackwell, Oxford.

SNYDER, L. H. (1929). The blood groups of the Jamaicans. In Race Crossing in Jamaica, by Davenport, C. B., and Steggerda, M., p. 277. Carnegie Institution of Washington, Publ. No. 395.

Stafford, J. L., Hill, K. R., and Arneaud, J. D. (1955). Rhesus factor distribution in the Caribbean-preliminary communication. W. Indian med. J., 4, 119.

SteVens, W. L. (1952). Statistical analysis of the A-B-O system in mixed populations. Hum. Biol., 24, 12. 